\section{Response to: 'Variation in antinuclear antibody detection by automated indirect immunofluorescence analysis' by van Hoovels et al}

We thank van Hoovels et $a l^{1}$ for their comments on our article ${ }^{2}$ on the variability of antinuclear antibody (ANA) determinations; other letters also discussed ANA testing issues. ${ }^{34}$ Meroni et al noted the value of distinguishing staining patterns by immunofluorescence assays (IFAs). ${ }^{3}$ In his discussion, Dr Mahler recommended the use of automated or computer-assisted diagnostic (CAD) systems as a way to reduce the variability and subjectivity that can occur with visual reading of IFA for ANA determinations. ${ }^{4}$ As the data presented by Van Hoovels and colleagues in their letter indicate, even automated systems have limitations. A prior publication on CAD systems highlighted quality assurance approaches to address these problems. ${ }^{5}$

Clearly, even with well-validated assays that include CAD interpretation, available ANA assays show variability. This variability can affect diagnostic evaluation and decision-making; in the context of clinical trials for 'active, autoantibody positive' disease, these assay issues can determine trial entry and lead to screen failures. Furthermore, assay variability could affect the prescription of agents that have been approved for patients who are ANA or anti-DNA positive. We, therefore, welcome further discussion on ANA testing and the opportunity to develop more robust and reproducible assays as well as to achieve greater harmonisation with existing platforms.

\section{David S Pisetsky, ${ }^{1}$ Diane M Spencer, ${ }^{1}$ Peter E Lipsky, ${ }^{2}$ Brad H Rovin ${ }^{3}$}

${ }^{1}$ Department of Medicine and Immunology, Duke University Medical Center and Medical Research Service, Veterans Administration Medical Center, Durham, North Carolina, USA

${ }^{2}$ RILITE Research Institute, Charlottesville, Virginia, USA

${ }^{3}$ Division of Nephrology, The Ohio State University, Wexner Medical Center, Columbus, Ohio, USA
Correspondence to Dr David S Pisetsky, Department of Medicine and Immunology, Duke University Medical Center, Durham, NC 27705, USA; david.pisetsky@duke.edu

Handling editor Josef S Smolen

Competing interests None declared.

Patient consent Not required.

Provenance and peer review Commissioned; internally peer reviewed.

(C) Article author(s) (or their employer(s) unless otherwise stated in the text of the article) 2019. All rights reserved. No commercial use is permitted unless otherwise expressly granted.

\section{Check for updates}

To cite Pisetsky DS, Spencer DM, Lipsky PE, et al. Ann Rheum Dis 2019;78:e49.

Received 26 April 2018

Accepted 26 April 2018

Published Online First 5 May 2018

\section{S Linked}

http://dx.doi.org/10.1136/annrheumdis-2018-213543

Ann Rheum Dis 2019;78:e49. doi:10.1136/annrheumdis-2018-213558

\section{REFERENCES}

1 Van Hoovels L, Schouwers S, Van den Bremt S, et al. Variation in antinuclear antibody detection by automated indirect immunofluorescence analysis. Ann Rheum Dis 2019;78:e48

2 Pisetsky DS, Spencer DM, Lipsky PE, et al. Assay variation in the detection of antinuclear antibodies in the sera of patients with established SLE. Ann Rheum Dis 2018;77:911-3.

3 Meroni PL, Chan EK, Damoiseaux J, et al. Unending story of the indirect immunofluorescence assay on HEp-2 cells: old problems and new solutions? Ann Rheum Dis 2019;78:e46.

4 Mahler M. Lack of standardisation of ANA and implications for drug development and precision medicine. Ann Rheum Dis 2019;78:e33.

5 Van den Bremt S, Schouwers S, Van Blerk M, et al. ANA IIF automation: moving towards harmonization? Results of a multicenter study. J Immunol Res 2017;2017:1-7. 